
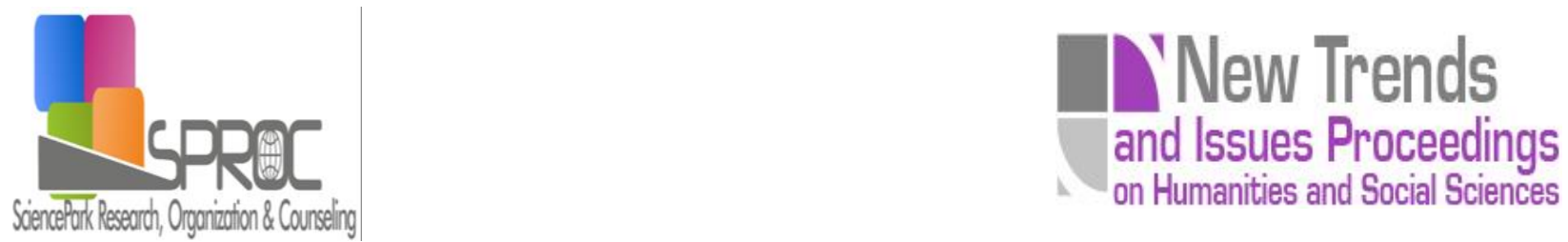

\title{
The notion of childhood in non-governmental organizations
}

Neslihan Avci *

Nihan Koran ${ }^{b}$

Suggested Citation:

Proceedings on Humanities and Social Sciences.

New Trends and Issues

Abstract 
on Humanities and Social Sciences.

1. Introduction

sentiment de l'enfance

$\bullet$ 
on Humanities and Social Sciences.

$\bullet$

-
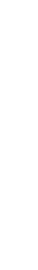

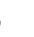

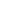

1. Method 
on Humanities and Social Sciences. 
Our agenda and priority is to protect children and to ensure their well-being... We work diligently with utmost dedication to ensure the well-being and development of children.

Our goals is to find and help children who are being forced to beg or to work under harsh conditions by their families... The thanks of children hugging us with their feeble and tired arms is what gives us hope and strength..."

Children are not the 'subjects' of our work, but rather our working partners. We work together with children to promote their self-development as individuals... Network activities and participation programs are primarily conducted together with children, who are our main working partners and friends.

Our association focuses on providing out-of-school education support to elementary school children..." "The prerequisite of a brighter future and brighter faces is giving the best education to our children..." 
on Humanities and Social Sciences. 


\section{References}

\section{Cocuk odakli habercilik}

Young children's rights: Exploring beliefs, principles and practice.

Children rights and childhood

Anyone listening? Evidence of children and young people's participation in England

Children, participation, projects - how to make it work!.

Qualitative, quantitative, and mixed methods approach

Degisen dunyada cocuk yetistirme ve egitim[Raising and educating children in a changing world]. Dunya'da ve Turkiye'de degisen cocukluk III. Ulusal Cocuk Kulturu kongresi bildirileri

The new handbook of children's rights comparative policy and practices

Baba bana top at!: Bati'da cocuklugun tarihi

Graduate Journal of Social Science, 2

Cocuklarin gelisen kapasiteleri [The envolving capacities of the child] 